\title{
Carnosine uptake in rat choroid plexus primary cell cultures and choroid plexus whole tissue from PEPT2 null mice
}

\author{
Nathan S. Teuscher, $*$ Hong Shen, ${ }^{*}$ Cathaleen Shu, ${ }^{*}$ Jianming Xiang, $\dagger$ Richard F. Keep, $\dagger$ \\ and David E. Smith* \\ *Department of Pharmaceutical Sciences, College of Pharmacy, and Upjohn Center for Clinical Pharmacology and \\ $\dagger$ Department of Neurosurgery and Physiology, The University of Michigan, Ann Arbor, Michigan, USA
}

\begin{abstract}
PEPT2 is functionally active and localized to the apical membrane of rat choroid plexus epithelial cells. However, little is known about the transport mechanisms of endogenous neuropeptides in choroid plexus, and the role of PEPT2 in this process. In the present study, we examined the uptake kinetics of carnosine in rat choroid plexus primary cell cultures and choroid plexus whole tissue from wild-type (PEPT2 ${ }^{+/+}$) and null (PEPT2 ${ }^{--}$) mice. Our results indicate that carnosine is preferentially taken up from the apical as opposed to basolateral membrane of cell monolayers, and that basolateral efflux in limited. Transepithelial flux of carnosine was not distinguishable from that of paracellular diffusion. The
\end{abstract}

apical uptake of carnosine was characterized by a high affinity $\left(K_{\mathrm{m}}=34 \mu \mathrm{m}\right)$, low capacity $\left(V_{\max }=73 \mathrm{pmol} / \mathrm{mg}\right.$ protein $\left./ \mathrm{min}\right)$ process, consistent with that of PEPT2. The non-saturable component was small $\left(K_{\mathrm{d}}=0.063 \mu \mathrm{L} / \mathrm{mg}\right.$ protein $\left./ \mathrm{min}\right)$ and, under linear conditions, was only $3 \%$ of the total uptake. Studies in transgenic mice clearly demonstrated that PEPT2 was responsible for over $90 \%$ of carnosine's uptake in choroid plexus whole tissue. These findings elucidate the unique role of PEPT2 in regulating neuropeptide homeostasis at the blood-cerebrospinal fluid interface.

Keywords: carnosine, choroid plexus, neuropeptides, PEPT2, transport.

J. Neurochem. (2004) 89, 375-382.
Carnosine ( $\beta$-alanyl-L-histidine) is present in muscle and the central nervous system. Although the physiological function of carnosine is not fully understood, many putative roles have been assigned to this dipeptide. In this regard, it may act as a neuroprotective agent against free radicals (Boldyrev et al. 1997), inhibit protein glycosylation from reactive aldehydes (Hipkiss et al. 1998), or act as a scavenger for reactive oxygen species (Stvolinsky et al. 1999). Carnosine reduces the toxicity of $\beta$-amyloid, the primary neurotoxin in Alzheimer's disease (Preston et al. 1998), and prevents $\beta$-amyloid aggregation (Hipkiss 1998). It has also been implicated in protection from metal-induced cell toxicity (Horning et al. 2000). Finally, carnosine is present in high concentrations (1-2 mM) in the olfactory bulb (Margolis 1974) and may serve as a neurotransmitter in this region (Marchis et al. 2000).

PEPT2, a proton-coupled oligopeptide transporter, is responsible for the high-affinity symport of di-/tripeptides across biological membranes via an inwardly directed electrochemical proton gradient. Although initially cloned from human kidney (Liu et al. 1995), this peptide transporter was subsequently cloned from rat brain and found to be identical to rat kidney PEPT2 (Wang et al. 1998). PEPT2 transcripts are found throughout the brain and abundantly expressed in epithelial cells of the choroid plexus (Berger and Hediger 1999). Moreover, molecular and functional studies conclusively demonstrate that PEPT2 protein is expressed in choroid plexus tissue and, in particular, on the apical membrane surface of choroidal epithelia (Novotny et al. 2000; Teuscher et al. 2000, 2001; Shu et al. 2002). In this capacity, PEPT2 is believed to act as an efflux pump in

Received October 14, 2003; revised manuscript received December 8, 2003; accepted December 9, 2003.

Address correspondence and reprint requests to Dr David E. Smith, 4302A Upjohn Center, 1310 E. Catherine Street, The University of Michigan, Ann Arbor, Michigan 48109-0504, USA.

E-mail: smithb@umich.edu

Abbreviations used: aCSF, artificial CSF; BCSFB, blood-CSF barrier; DMEM, Dulbecco's modified Eagle's medium; GABA, $\gamma$-amino-nbutyric acid; GlyGln, glycylglutamine; GlySar, glycylsarcosine; HEPES, $\mathrm{N}$-2-hydroxyethylpiperazine- $\mathrm{N}^{\prime}$-2-ethanesulfonic acid; HPLC, high-performance liquid chromatography; $\mathrm{NMN}, \mathrm{N}^{1}$-methylnicotinamide; $\mathrm{PAH}$, p-aminohippuric acid; SITS, 4-acetamido-4'-isothiocyanatostilbene-2, 2'-disulfonic acid; TCA, taurocholic acid; TEA, tetraethylammonium. 
the removal of neuropeptides and peptide fragments from cerebrospinal fluid (CSF).

Still, a clear understanding of neuropeptide transport at the choroid plexus is lacking. This is due, in part, to the fact that most choroid plexus studies were performed using a synthetic, model dipeptide (i.e. glycylsarcosine), non-physiologic buffer conditions (e.g. Tris-Mes, acidic $\mathrm{pH}$, low sodium), and whole tissue uptakes that could neither differentiate membrane sidedness nor directionality. In addition, the presence of two peptide/histidine transporters in brain (i.e. PHT1 and PHT2) (Yamashita et al. 1997; Sakata et al. 2001) makes it difficult to accurately determine the significance of PEPT2 relative to other (peptide) transporters. Notwithstanding this uncertainty, it was reported that PEPT2 accounted for about $60 \%$ of the total uptake of carnosine in whole tissue rat choroid plexus (Teuscher et al. 2001). However, this conclusion is quite tenuous, as suggested by other studies in PEPT2 null mice (Shen et al. 2003).

With this in mind, we used rat choroid plexus epithelial cells in primary culture to investigate the peptide-mediated transport mechanisms of an endogenous neuropeptide, carnosine, at the blood-CSF interface. We also evaluated the whole tissue choroid plexus uptake of carnosine in wildtype and PEPT2-deficient mice. Taken as a whole, these results indicate that apical PEPT2 is the predominant transporter in regulating neuropeptide homeostasis in cerebrospinal fluid.

\section{Experimental procedures}

\section{Materials}

$[3 \mathrm{H}]$ Carnosine $(9 \mathrm{Ci} / \mathrm{mmol})$ was purchased from Moravek Biochemicals (Brea, CA, USA) and $\left[{ }^{14} \mathrm{C}\right]$ mannitol $(53 \mathrm{mCi} / \mathrm{mmol})$ was purchased from American Radiolabeled Chemicals (St Louis, MO, USA). Amino acids ( $\beta$-alanine and L-histidine), carnosine, glycylglutamine (GlyGln), glycylsarcosine (GlySar), 4-acetamido-4'-isothiocyanatostilbene-2,2'-disulfonic acid (SITS), taurocholic acid (TCA), $\gamma$-amino-n-butyric acid (GABA), p-aminohippuric acid (PAH), $\quad \mathrm{N}^{1}$-methylnicotinamide $(\mathrm{NMN}), \quad$ tetraethylammonium (TEA) and choline were purchased from Sigma (St Louis, MO, USA). Other chemicals were obtained from standard sources and were of the highest quality available.

\section{Culture medium and uptake buffers}

The cell culture medium consisted of Dulbecco's modified Eagle's medium (DMEM)/F-12 (1:1) supplemented with $10 \%(\mathrm{v} / \mathrm{v})$ fetal bovine serum, $15 \mathrm{~mm}$ HEPES, $2 \mathrm{~mm}$ L-glutamine, 100 units $/ \mathrm{mL}$ penicillin $\mathrm{G}$ sodium, $1 \mu \mathrm{g} / \mathrm{mL}$ streptomycin sulfate, $25 \mu \mathrm{g} / \mathrm{mL}$ gentamicin, $5 \mathrm{mg} / \mathrm{mL}$ insulin, $10 \mathrm{ng} / \mathrm{mL}$ epidermal growth factor, $2 \mu \mathrm{g} / \mathrm{mL}$ hydrocortisone, $5 \mu \mathrm{g} / \mathrm{mL}$ transferrin, and $5 \mathrm{ng} / \mathrm{mL}$ sodium selenite ( $\mathrm{pH}$ 7.3) (all reagents from Life Technologies, Rockville, MD, USA).

Experiments were performed in normal- $\mathrm{Na}^{+}$artificial cerebrospinal fluid (aCSF) and low- $\mathrm{Na}^{+}$aCSF. The normal- $\mathrm{Na}^{+}$aCSF buffer (about $310 \mathrm{mOsm} / \mathrm{kg}$ ) contained $127 \mathrm{~mm} \mathrm{NaCl}, 20 \mathrm{~mm}$
$\mathrm{NaHCO}_{3}, 2.4 \mathrm{~mm} \mathrm{KCl}, 0.5 \mathrm{~mm} \mathrm{KH}_{2} \mathrm{PO}_{4}, 1.1 \mathrm{~mm} \mathrm{CaCl}, 0.85 \mathrm{~mm}$ $\mathrm{MgCl}_{2}, 0.5 \mathrm{~mm} \mathrm{Na}_{2} \mathrm{SO}_{4}$, and $5.0 \mathrm{~mm}$ glucose. In the low- $\mathrm{Na}^{+}{ }_{\mathrm{aCSF}}$ buffer, $\mathrm{NaCl}$ and $\mathrm{NaHCO}_{3}$ were replaced with choline chloride and choline bicarbonate, respectively, producing a $1.0 \mathrm{~mm}$ sodium solution due to the presence of $\mathrm{Na}_{2} \mathrm{SO}_{4}$. Both buffers were adjusted to $\mathrm{pH} 7.4$ with $\mathrm{HCl}$.

Primary culture of choroid plexus epithelial cells

Primary cultures of rat choroid plexus epithelial cells were prepared from 1 to 2 day-old neonatal rats using an established method (Strazielle and Ghersi-Egea 1999; Shu et al. 2002). Cells were isolated from lateral ventricles and seeded on laminin-coated Transwell-Clear filter inserts (12-mm diameter, $0.4-\mu \mathrm{m}$ pore size; Costar Plastics, Cambridge, MA, USA). The culture medium was changed at $48-72 \mathrm{~h}$ after seeding and every other day thereafter. Cells were grown in a sterile incubator at $37^{\circ} \mathrm{C}, 95 \%$ relative humidity and $5 \% \mathrm{CO}_{2}$. Cultures were inspected visually for epithelial growth (cobblestone appearance) on a weekly basis. Confluence occurred at 5-7 days post-seeding. Transepithelial electrical resistance measurements were performed prior to experimentation (using a Millicell-ERS; Millipore Corp., Bedford, MA, USA) as a measure of monolayer integrity. Values of $150 \Omega \bullet \mathrm{cm}^{2}$ were reached at 10-14 days post-seeding and were considered sufficient for experimentation.

\section{Carnosine intracellular accumulation and transepithelial transport in cell cultures}

Cells were incubated apically $(0.4 \mathrm{~mL})$ and basolaterally $(1.2 \mathrm{~mL})$ in uptake buffer (normal-Na ${ }^{+}$aCSF or low- $\mathrm{Na}^{+} \mathrm{aCSF}$ ) at $37^{\circ} \mathrm{C}$ for $10 \mathrm{~min}$ prior to experimentation. The buffer was removed and fresh uptake buffer, containing $0.4 \mu \mathrm{Ci}\left[{ }^{3} \mathrm{H}\right]$ carnosine and $0.1 \mu \mathrm{Ci}$ $\left[{ }^{14} \mathrm{C}\right]$ mannitol, was added to the apical $(0.4 \mathrm{~mL})$ or basolateral $(1.2 \mathrm{~mL})$ chamber; control buffer (no radioisotope) was added to the opposite chamber. Potential inhibitors $(1 \mathrm{~mm})$ were added to the same side as carnosine. The cells were then incubated at $37^{\circ} \mathrm{C}$ for the indicated time. To measure transepithelial transport, a $100 \mu \mathrm{L}$ sample was taken from the opposite chamber and placed in a scintillation vial. To measure intracellular accumulation, the uptake buffer was aspirated at the end of the incubation period. Three successive rapid washings with ice-cold uptake buffer were then performed. The filter and monolayer were detached and placed in a scintillation vial with $0.5 \mathrm{~mL}$ of $0.2 \mathrm{M} \mathrm{NaOH}$ and $1 \%$ sodium dodecyl sulfate (SDS). Scintillation cocktail [EcoLite(+); ICN, Costa Mesa, CA, USA] was added to the solubilized cells and radioactivity was determined in the sample using a dual-channel liquid scintillation counter (Beckman LS 6000; Fullerton, CA, USA). The protein content of the solubilized cell monolayers was determined by the method of Bradford (1976), using a Bio-Rad protein assay kit (Bio-Rad Laboratories, Hercules, CA, USA) with immunoglobulin $\mathrm{G}$ as the standard.

Carnosine uptake data were corrected for filter binding and extracellular content, as described previously (Teuscher et al. 2000). The transepithelial transport of carnosine was corrected for paracellular flux, as estimated by mannitol (Shu et al. 2002).

\section{Efflux experiments in cell cultures}

Cells were washed twice with normal- $\mathrm{Na}^{+}$aCSF buffer and then incubated apically $(0.4 \mathrm{~mL})$ and basolaterally $(1.2 \mathrm{~mL})$ in this buffer 
at $37^{\circ} \mathrm{C}$ for $10 \mathrm{~min}$ prior to experimentation. The buffer was removed and fresh uptake buffer containing $1 \mu \mathrm{M}\left[{ }^{3} \mathrm{H}\right]$ carnosine was added to the apical chamber $(0.4 \mathrm{~mL})$; control buffer (no radioisotope) was added to the basolateral chamber. The cells were then incubated at $37^{\circ} \mathrm{C}$ for 2 hours. The cells were removed and washed six times with warm buffer. Fresh normal- $\mathrm{Na}^{+} \mathrm{aCSF}$ buffer was then added to the apical $(0.4 \mathrm{~mL})$ and basolateral $(1.2 \mathrm{~mL})$ chambers. At the indicated times, a $100-\mu \mathrm{L}$ aliquot was sampled from the apical and basolateral chambers, and added to a scintillation vial. At the final time point, the cell monolayers were washed and removed, and placed in a scintillation vial with lysis buffer. Scintillation cocktail [Ecolite(+); ICN, Costa Mesa, CA, USA] was added to the samples and radioactivity determined using a dual-channel liquid scintillation counter (Beckman LS 6000). Efflux was expressed as the per cent of total substrate in the cells after loading.

\section{Carnosine stability in cell cultures}

Choroid plexus epithelial cells were incubated apically with $1 \mu \mathrm{M}$ $\left[{ }^{3} \mathrm{H}\right]$ carnosine for 15, 30, 60 and $120 \mathrm{~min}$. At the end of incubation, media from the apical and basolateral compartments were aspirated and saved for analysis. The cell monolayers were washed three times with ice-cold buffer and solubilized in $0.5 \mathrm{~mL}$ of $0.2 \mathrm{M} \mathrm{NaOH}$ and $1 \%$ SDS. The samples were then analyzed by high-performance liquid chromatography (HPLC), and the concentration of radiolabeled carnosine and its potential degradation product, histidine, was determined. The stability of carnosine was evaluated by its recovery and the appearance of histidine following incubation. Results were reported from three separate experiments.

An analytical method was developed based on work done by O'Dowd et al. (1990). Carnosine and histidine were detected using an HPLC system consisting of a pump (Waters, Model 616, Milford, MA, USA), a controller (Waters, Model 600S), a reversed-phase column (Hypersil ODS, C-18, $5 \mu \mathrm{m}, 250 \mathrm{~mm} \times 4.6 \mathrm{~mm}$, Alltech, Deerfield, IL, USA) and a radiochromatography detector (FLOONE 500TR, Packard Instrument Co., Meriden, CT, USA). The mobile phase was comprised of $0.1 \mathrm{M} \mathrm{Na} \mathrm{NPO}_{4}$ and $0.13 \%$ heptafluorobutryic acid, and pumped isocratically at $1 \mathrm{~mL} / \mathrm{min}$ at room temperature $\left(23^{\circ} \mathrm{C}\right)$. Retention times for histidine and carnosine were 6.9 and $18.5 \mathrm{~min}$, respectively.

\section{Endogenous carnosine}

Skeletal muscle (600 mg), olfactory bulb (450 mg), choroid plexus $(70 \mathrm{mg})$, cerebrospinal fluid $(200 \mu \mathrm{L})$ and plasma $(3 \mathrm{~mL})$ were obtained from anesthetized adult female rats, and processed accordingly (O’Dowd et al. 1990). In brief, tissue samples were homogenized in $2 \mathrm{~mL}$ of water. An 8-mL aliquot of ethanol was added to the homogenized tissue and body fluid samples, and the mixture was vortexed and then incubated at $60^{\circ} \mathrm{C}$ for $90 \mathrm{~min}$. After incubation, the precipitate was pelleted by centrifugation $(2000 \mathrm{~g}, 15 \mathrm{~min})$. The supernatant was removed, evaporated to dryness, and then reconstituted in mobile phase. Carnosine was detected at $210 \mathrm{~nm}$ using a UV spectrophotometer (Spectroflow 783; ABI Analytical, Chestnut Ridge, NY, USA) coupled to HPLC (as described above).

\section{Carnosine uptake in isolated choroid plexuses of PEPT2 ${ }^{+/+}$ and PEPT2 $2^{-/-}$mice}

Whole tissue choroid plexus uptakes were performed in 30-50-dayold $\mathrm{PEPT}^{+/+}$(wild-type) and $\mathrm{PEPT}^{-/-}$(null) mice, as described previously for GlySar (Shen et al. 2003). In brief, lateral and fourth ventricle choroid plexuses were harvested from anesthetized mice, transferred to pre-weighed eppendorf tubes and re-weighed to $0.1 \mathrm{mg}$ accuracy using an electronic balance (Mettler AE100; Toledo, OH, USA) to determine plexus weight. They were then immediately transferred to normal- $\mathrm{Na}^{+}$aCSF buffer $(\mathrm{pH}$ 7.4) which was continuously bubbled with $5 \% \mathrm{CO}_{2}, 95 \% \mathrm{O}_{2}$. After a 5 -min recovery period, the choroid plexuses were transferred to $0.95 \mathrm{~mL}$ of fresh buffer for $0.5 \mathrm{~min}$. Uptake was initiated by addition of $0.05 \mathrm{~mL}$ of normal- $\mathrm{Na}^{+}$aCSF buffer containing about $0.2 \mu \mathrm{Ci}$ of $\left[{ }^{3} \mathrm{H}\right]$ carnosine (plus $20 \mu \mathrm{M}$ unlabeled carnosine) and $0.2 \mu \mathrm{Ci}$ of $\left[{ }^{14} \mathrm{C}\right]$ mannitol (an extracellular marker), resulting in a final carnosine concentration of $1.0 \mu \mathrm{M}$. Uptake was terminated after 2 min by transferring the plexuses to ice-cold buffer and filtering under reduced pressure. The filters $(118-\mu \mathrm{m}$ mesh, Tetko, Kansas City, MO, USA) were washed three times with the same buffer. The filters and choroid plexuses were then soaked in $0.33 \mathrm{~mL}$ of $1 \mathrm{M}$ hyamine hydroxide (a tissue solubilizer) for $30 \mathrm{~min}$ before the addition of scintillation cocktail (Cytoscint) and counting with a dual-channel liquid scintillation counter (Beckman LS 3801). Similar uptake studies were performed for carnosine in low- $\mathrm{Na}^{+}$ aCSF buffer ( $\mathrm{pH}$ 7.4). The uptake of radiolabeled carnosine into choroid plexus ( $V_{\mathrm{d}}$, in $\mu \mathrm{L} / \mathrm{mg}$ of wet tissue weight) was calculated as described previously (Teuscher et al. 2000).

All of the rat and mice experiments were carried out in accordance with animal care guidelines and with the approval of the University of Michigan Committee for the Care and Use of Animals.

\section{Data analysis}

For concentration-dependent studies in cell cultures, the data were best fit to the equation: carnosine uptake $=V_{\max } ? \mathrm{C} /\left(K_{\mathrm{m}}+\mathrm{C}\right)+K_{\mathrm{d}}$ ? C, where $V_{\max }$ is the maximal rate of saturable carnosine uptake, $K_{\mathrm{m}}$ is the Michaelis constant, C is the substrate (carnosine) concentration, and $K_{\mathrm{d}}$ is the non-saturable rate constant. To evaluate if more than one class of transporters was operational for carnosine, a Woolf-Augustinsson-Hofstee transformation of the saturable portion of uptake $\left(V=\right.$ carnosine uptake $-K_{\mathrm{d}}$ ? C) was performed in which: $V=V_{\max }-K_{\mathrm{m}} ? V / \mathrm{C}$.

Statistical comparisons were performed with ANOVA (SYSTAT, version 8.0; SPSS Inc., Chicago, IL, USA) and pairwise comparisons were made with Dunnett's test. A probability of $p=0.05$ was considered statistically significant. Linear and non-linear regression analyses were performed with SCIENTIST (version 2.01; MicroMath Scientific Software, Salt Lake City, UT, USA) and a weighting factor of unity. The quality of fit was determined by evaluating the coefficient of determination $\left(r^{2}\right)$, the standard error of parameter estimates, and by visual inspection of the residuals. Data are reported as mean $\pm \mathrm{SE}$.

\section{Results}

Apical versus basolateral uptake and efflux of carnosine in cell cultures

The time course of $\left[{ }^{3} \mathrm{H}\right]$ carnosine uptake in normal- $\mathrm{Na}^{+}$ aCSF is shown in Fig. 1. The uptake rate was 5-6 times 


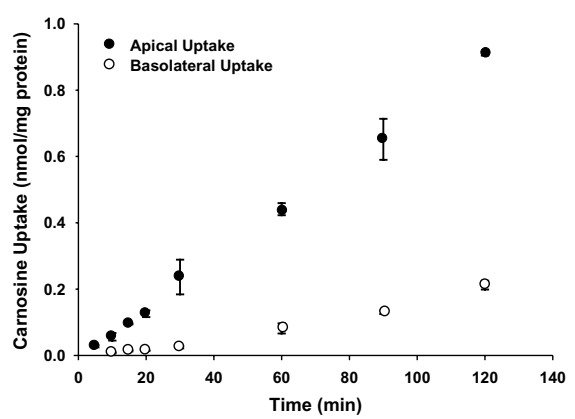

Fig. 1 Uptake amount of $\left[{ }^{3} \mathrm{H}\right]$ carnosine as a function of time from cell monolayers $(1 \mu \mathrm{m}$ carnosine in external medium). $(\bullet)$ Uptake from the apical chamber; $(\odot)$ uptake from the basolateral chamber. Uptake is linear through $120 \mathrm{~min}$ from both the apical and basolateral sides. Studies were performed using normal- $\mathrm{Na}^{+}$aCSF buffer, $\mathrm{pH} 7.4$, in both chambers. Data are expressed as mean \pm SE $(n=3-6)$.

greater from the apical than from the basolateral surface. The apical uptake was linear through $120 \mathrm{~min}$, at which time there was approximately a $135: 1$ ratio of intracellular to extracellular carnosine, indicating active accumulation from CSF into the cell. Based on these results, a 60-min incubation time was chosen for initial rate uptakes of carnosine in order to maximize its sensitivity for kinetic and amino acid/ dipeptide inhibitor studies. Alternatively, a 15-min incubation time was chosen for carnosine studies with charged compounds (i.e. organic anion or cation inhibitors) so that potential intracellular and/or extracellular $\mathrm{pH}$ changes would be minimized. Stability was not an issue in our experimental system as $\geq 99.3 \%$ of carnosine was recovered intact from the apical, basolateral and intracellular compartments, even after 2 hours of incubation.

To probe the fate of carnosine once in the cell, efflux was examined after a 2-h pre-loading period. As shown in Fig. 2,

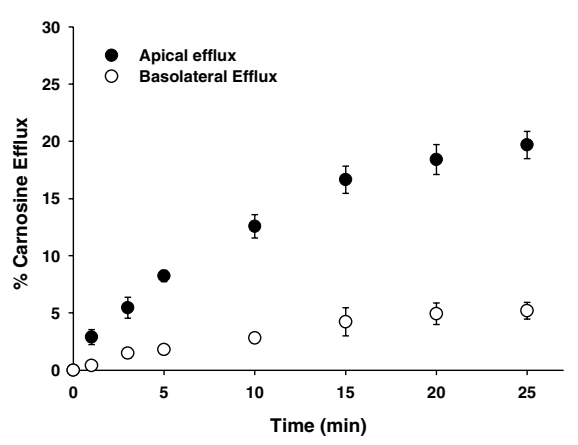

Fig. 2 Efflux of $\left[{ }^{3} \mathrm{H}\right]$ carnosine as a function of time from cell monolayers (after loading for $2 \mathrm{~h}$ with $1 \mu \mathrm{m}\left[{ }^{3} \mathrm{H}\right]$ carnosine). (•) Efflux into the apical chamber; $(\odot)$ efflux into the basolateral chamber. Data reported as per cent of total carnosine effluxed at a given time point. Studies were performed using normal- $\mathrm{Na}^{+}$aCSF buffer, $\mathrm{pH} 7.4$, in both chambers. Data are expressed as mean $\pm \mathrm{SE}(n=3-6)$. at $25 \mathrm{~min}$, about $20 \%$ of $\left[{ }^{3} \mathrm{H}\right]$ carnosine was effluxed to the apical chamber while only $5 \%$ was effluxed to the basolateral chamber. The apical efflux was similar to values determined previously for GlySar in rat choroid plexus primary cell cultures (Shu et al. 2002). Although the uptake of carnosine occurred primarily at the apical membrane, its apical to basal transport could not be discerned from that of mannitol alone (data not shown). The lack of measurable transepithelial transport agrees with very minor efflux of carnosine into the basolateral compartment. Due to the dominance of carnosine's apical uptake, along with PEPT2 being localized to the apical surface of choroid plexus epithelial cells, the specificity and kinetic properties of carnosine were characterized further at this membrane surface alone.

\section{Apical uptake of carnosine \pm inhibitors in cell cultures} The specificity of peptide-mediated transport was examined using physiologic normal- $\mathrm{Na}^{+}$aCSF versus low- $\mathrm{Na}^{+}$aCSF buffer and a wide variety of potential inhibitors. As shown in Fig. 3(a) (physiologic buffer), neither $\beta$-alanine nor L-histidine, the constituent amino acids of carnosine, were able to inhibit uptake. However, unlabeled carnosine as well as two dipeptides, GlyGln and GlySar, reduced $\left[{ }^{3} \mathrm{H}\right]$ carnosine uptake to values that were $5-10 \%$ of control. A similar inhibition profile was observed when radiolabeled carnosine was studied under low sodium conditions (Fig. 3b). As observed in Fig. 4(a) (physiologic buffer), the uptake of carnosine was inhibited $30-40 \%$ by the organic anions SITS and GABA, but not by TCA or PAH. In contrast, there was no inhibition of carnosine by organic acids when studied in low sodium buffer (Fig. 4b). Carnosine was also inhibited $35-40 \%$ by the organic cations NMN and TEA, but not by choline (Fig. 5a, physiologic buffer). However, carnosine was not inhibited by organic cations when studied under low sodium conditions (Fig. 5b).

\section{Apical uptake kinetics of carnosine in cell cultures}

The inhibition studies suggested that carnosine may be transported across the apical membrane by sodium-independent (i.e. PEPT2) and sodium-dependent processes. In order to assure the specificity of kinetic parameters, the saturable uptake of carnosine was determined in low- $\mathrm{Na}^{+}$ aCSF buffer. This buffer has been shown to be advantageous in studying the PEPT2-mediated transport of dipeptides in choroid plexus (Teuscher et al. 2000, 2001). As shown in Fig. 6, the apical uptake of carnosine was of high affinity in which $K_{\mathrm{m}}$ and $V_{\max }$ values were estimated at $34 \pm 6 \mu \mathrm{M}$ and $73 \pm 5 \mathrm{pmol} / \mathrm{mg}$ protein $/ \mathrm{min}$, respectively. Moreover, $K_{\mathrm{d}}$ values were small (i.e. $0.063 \pm 0.007 \mu \mathrm{L} / \mathrm{mg}$ protein/min) and, as a result, the carrier-mediated transport accounted for $>97 \%$ of the total uptake under linear conditions. A Woolf-Augustinsson-Hofstee plot of the saturable data (Fig. 6, inset) was also linear $\left(r^{2}=0.829\right)$, 
(a)

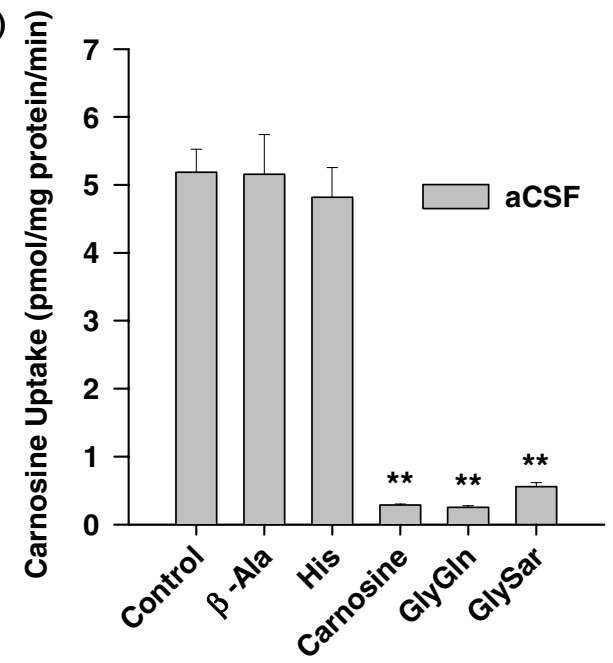

(b)

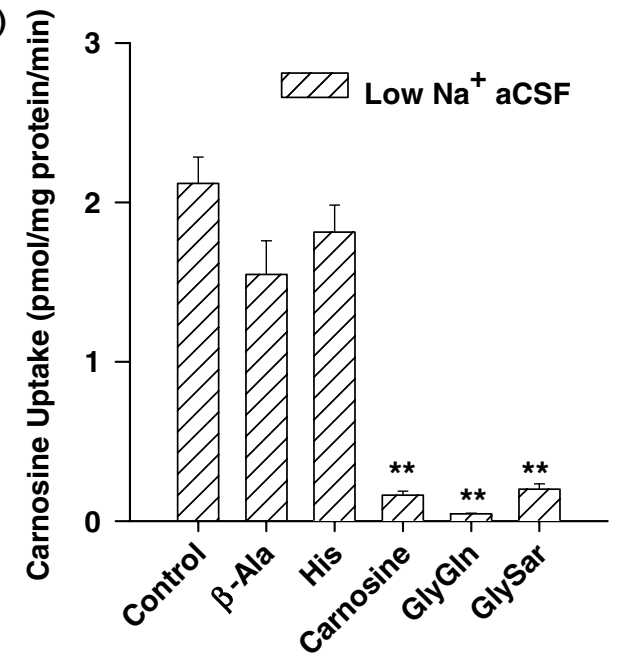

Fig. 3 Effect of amino acids or dipeptides on the apical uptake of $\left[{ }^{3} \mathrm{H}\right]$ carnosine from cell monolayers ( $1 \mu \mathrm{m}$ carnosine in external medium; inhibitor concentrations at $1 \mathrm{~mm}$ ). Studies were performed using normal- $\mathrm{Na}^{+}$aCSF buffer, $\mathrm{pH} 7.4$, in both chambers (a) or low-Na ${ }^{+}$ aCSF buffer, $\mathrm{pH} 7.4$, in both chambers (b). Data are expressed as mean \pm SE ( $n=6-10$ for controls; $n=3-6$ for inhibitors). ${ }^{* *} p<0.01$ as compared with control values.

indicating that a single transport system was functioning under low- $\mathrm{Na}^{+}$conditions.

\section{Endogenous carnosine}

Given the substantial accumulation of carnosine in choroid plexus, the in vivo concentrations of carnosine were determined in several tissues and body fluids of rats. The results in Table 1 demonstrate that there is a significant amount of carnosine stored in the choroid plexus $(100 \mu \mathrm{mol} /$ $\mathrm{kg})$, as well as in the olfactory bulb $(830 \mu \mathrm{mol} / \mathrm{kg})$ and skeletal muscle $(1.78 \mathrm{mmol} / \mathrm{kg})$. In contrast, carnosine levels were below the limit of quantitation in CSF $(<2 \mu \mathrm{M})$ and plasma $(<0.4 \mu \mathrm{M})$. (a)

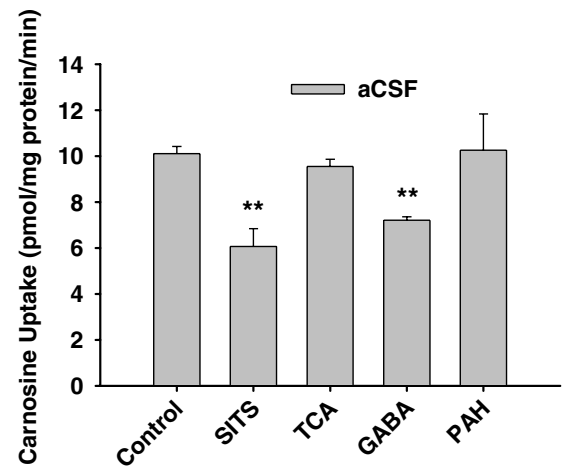

(b)

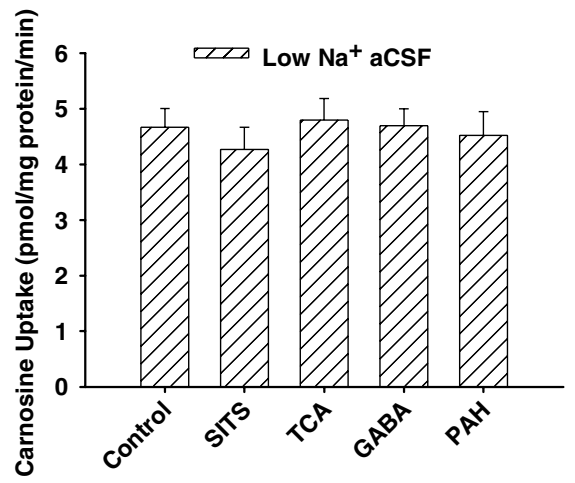

Fig. 4 Effect of organic anions on the apical uptake of $\left[{ }^{3} \mathrm{H}\right]$ carnosine from cell monolayers ( $1 \mu \mathrm{m}$ carnosine in external medium; inhibitor concentrations at $1 \mathrm{mM}$ ). Studies were performed using normal- $\mathrm{Na}^{+}$ aCSF buffer, $\mathrm{pH} 7.4$, in both chambers (a) or low- $\mathrm{Na}^{+}$aCSF buffer, $\mathrm{pH} 7.4$, in both chambers (b). Data are expressed as mean \pm SE ( $n=6-10$ for controls; $n=3-6$ for inhibitors). ${ }^{* *} p<0.01$ as compared with control values.

\section{Carnosine uptake in isolated choroid plexuses of $\mathrm{PEPT}^{+/+}$and PEPT2 ${ }^{-/-}$mice}

The uptake of carnosine was evaluated at $2 \mathrm{~min}$, a value that approximates initial rate uptake conditions in whole tissue choroid plexus. In the presence of physiologic normal- $\mathrm{Na}^{+}$ aCSF buffer (Fig. 7), carnosine uptake was virtually eliminated in PEPT2 $2^{-/}$mice as compared with that in $\mathrm{PEPT}_{2}^{+/+}$ mice $\left(V_{\mathrm{d}}=0.0436 \mu \mathrm{L} / \mathrm{mg}\right.$ vs. $1.10 \mu \mathrm{L} / \mathrm{mg}$, respectively; $p<0.0001)$. A similar reduction was observed using low$\mathrm{Na}^{+}$aCSF buffer $\left(V_{\mathrm{d}}=0.0481 \mu \mathrm{L} / \mathrm{mg}\right.$ in PEPT2 ${ }^{-/-}$mice vs. $0.675 \mu \mathrm{L} / \mathrm{mg}$ in PEPT2 ${ }^{+/+}$mice; $p<0.0001$ ). Under both conditions (i.e. normal and low sodium), the residual uptake of carnosine was $\leq 7 \%$ in PEPT2 null animals.

\section{Discussion}

The choroid plexus performs a number of essential functions in the brain. As the primary gatekeeper at the bloodcerebrospinal fluid barrier (BCSFB), the choroid plexus has a critical role in regulating the volume and composition of the interstitial fluid that surrounds the brain's neurons and 
(a)

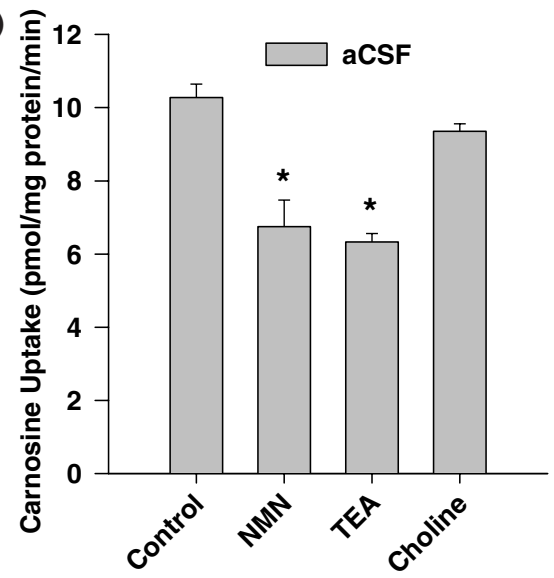

(b)

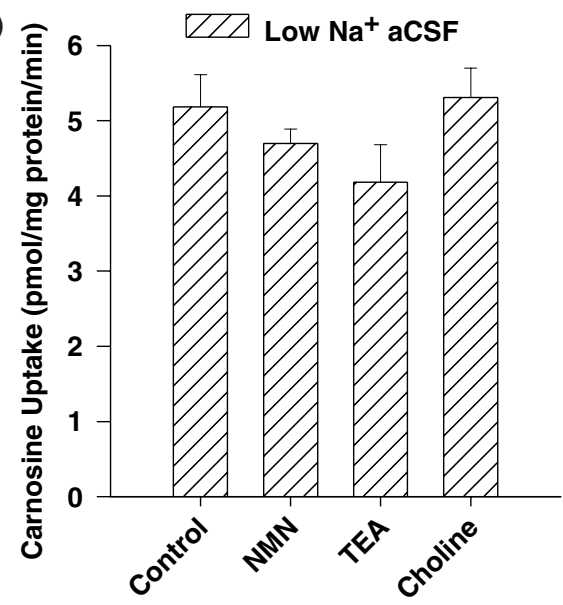

Fig. 5 Effect of organic cations on the apical uptake of $\left[{ }^{3} \mathrm{H}\right]$ carnosine from cell monolayers ( $1 \mu \mathrm{m}$ carnosine in external medium; inhibitor concentrations at $1 \mathrm{~mm}$ ). Studies were performed using normal- $\mathrm{Na}^{+}$ aCSF buffer, pH 7.4, in both chambers (a) or low- $\mathrm{Na}^{+}$aCSF buffer, $\mathrm{pH} 7.4$, in both chambers (b). Data are expressed as mean $\pm \mathrm{SE}$ ( $n=6-10$ for controls; $n=3-6$ for inhibitors). ${ }^{\star \star} p<0.01$ as compared with control values.

supportive glial cells. PEPT2 is expressed in choroid plexus, however, its physiological function is still unclear. Peptide transporters are known to serve a nutritive role in the intestine and as a mechanism for peptide conservation in the kidney (Leibach and Ganapathy 1996; Daniel and Herget 1997). Although PEPT2 may serve as a nutritive role by supplying peptides to the choroid plexus and CSF from blood, it more likely acts as a clearance mechanism to remove unwanted peptides or peptide fragments from the CSF. This belief is supported by studies on GlySar transport and directionality, and the apical localization of PEPT2 in choroid plexus (Teuscher et al. 2000; Shu et al. 2002). Because these papers focused on a synthetic dipeptide, there is little information on how endogenous peptides (and neuropeptides) are handled at the blood-CSF interface. Based on uptake studies in the absence and presence of

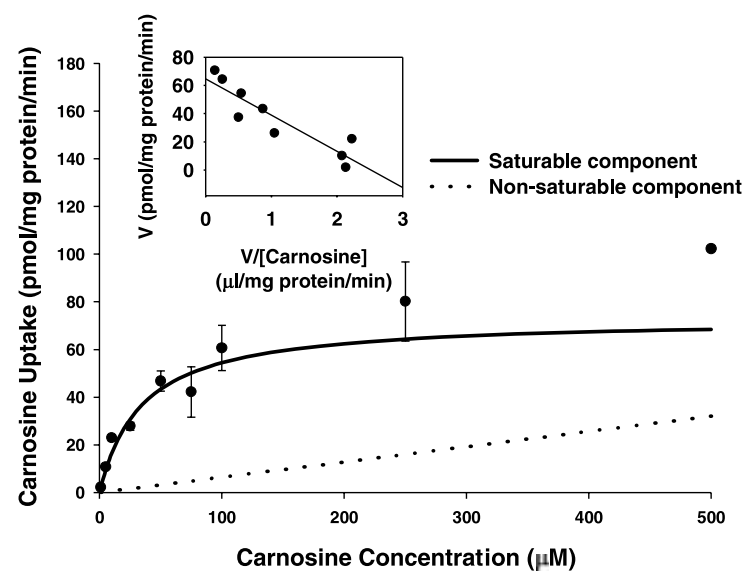

Fig. 6 Concentration-dependent apical uptake of $\left[{ }^{3} \mathrm{H}\right]$ carnosine from cell monolayers (1-500 $\mu \mathrm{m}$ total carnosine in external medium). Studies were performed using low- $\mathrm{Na}^{+}$aCSF buffer, $\mathrm{pH} 7.4$, in both chambers. The experimental data $(\bullet)$ are expressed as mean $\pm \mathrm{SE}$ $(n=3-6)$. The predicted curves were generated using the $V_{\max }, K_{\mathrm{m}}$ and $K_{d}$ values, as determined by non-linear regression $\left(r^{2}>0.990\right)$ and reported in the text. The insert is a Woolf-Augustinsson-Hofstee plot, which is linear $\left(r^{2}=0.829\right)$. Error bars are omitted for clarity in the insert.

sodium, preliminary studies have suggested that PEPT2 has a significant role in the choroid plexus uptake (about 30-60\%) of 5-aminolevulinic acid (Novotny et al. 2000), GlySar (Teuscher et al. 2000) and carnosine (Teuscher et al. 2001). However, a more recent study in PEPT2 knockout mice (Shen et al. 2003) demonstrated that this transporter was responsible for about $90 \%$ of the uptake of GlySar in isolated choroid plexus under optimized conditions (i.e. Tris-MES buffer, $\mathrm{pH}$ 6.5). The current studies use a combination of rat choroid plexus primary cell cultures and transgenic mice to further probe the role of PEPT2 in neuropeptide homeostasis in the CSF under physiologic conditions.

We found that carnosine exhibited a preferential uptake at the apical membrane of the choroid plexus epithelial cells. However, there was no measurable transcellular transport of carnosine from the apical to basolateral chambers. This finding is supported by the low basolateral efflux, which measured only $5 \%$ at $25 \mathrm{~min}$. Instead, it appears that once carnosine enters the choroid plexus from the CSF-facing side, it accumulates substantially within the cells, achieving concentrations $135 \times$ higher than that of extracellular medium and in vivo levels of $100 \mu \mathrm{mol} / \mathrm{kg}$. The culturing medium did not contain carnosine, which might suggest that our uptake studies demonstrate a replenishment of carnosine stores in various intracellular compartments. Our efflux results also indicate that some carnosine can recycle back to the CSF. The lack of carnosine transepithelial transport differs from studies by Shu et al. (2002) who demonstrated that GlySar was effluxed at the basolateral membrane. It is possible that carnosine and GlySar share a common uptake 
Table 1 Endogenous levels of carnosine from adult rat tissues

\begin{tabular}{llll}
\hline Tissue & $\begin{array}{l}\text { Concentration } \\
(\mathrm{mmol} / \mathrm{kg}) \\
\text { This Study }\end{array}$ & $\begin{array}{l}\text { Concentration } \\
(\mathrm{mmol} / \mathrm{kg}) \\
\text { Literature values }^{\mathrm{b}}\end{array}$ & References \\
\hline Skeletal muscle & $1.78 \pm 0.03$ & $0.7-1.36$ & $\begin{array}{l}\text { (Chung-Hwang et al. 1976; O'Dowd et al. 1990; Ward and Preedy 1992) } \\
\text { Olfactory bulb }\end{array}$ \\
Choroid plexus & $0.83 \pm 0.01$ & $0.9-2.7$ & - \\
CSF & $0.10 \pm 0.02$ & - & (Margolis 1974; Ferriero and Margolis 1975) \\
Plasma & $<$ LOQ & 0 & -
\end{tabular}

${ }^{a}$ Data are reported as mean $\pm \mathrm{SE}(n=3)$. ${ }^{\mathrm{b}} \mathrm{Data}$ are reported as range. ${ }^{\mathrm{C}} \mathrm{LOQ}$ represents the limit of quantitation $(0.002 \mathrm{mM}$ for CSF and $0.0004 \mathrm{~mm}$ for plasma).

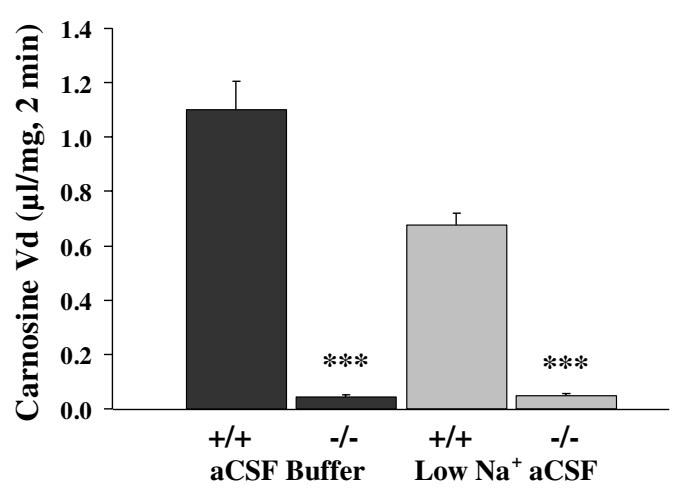

Fig. 7 Uptake of $\left[{ }^{3} \mathrm{H}\right]$ carnosine in the isolated choroid plexuses of $\mathrm{PEPT}^{+/+}$and $\mathrm{PEPT}^{-/-}$mice (1 $\mu \mathrm{m}$ carnosine in external medium). Studies were performed using normal- $\mathrm{Na}^{+}$aCSF buffer, $\mathrm{pH} 7.4$, or low- $\mathrm{Na}^{+}$aCSF buffer, $\mathrm{pH} 7.4$, in both genotypes. Data are expressed as mean \pm SE $(n=3-4) .{ }^{* \star} p<0.001$ as compared with wild-type animals.

pathway (i.e. PEPT2), but have different cellular efflux mechanisms at the basolateral membrane.

The apical uptake of carnosine was one of high affinity $\left(K_{\mathrm{m}}=34 \mu \mathrm{M}\right)$ and low capacity $\left(V_{\max }=73 \mathrm{pmol} / \mathrm{mg}\right.$ protein/min), and was consistent with a PEPT2-mediated process. In addition, the $K_{\mathrm{m}}$ determined for carnosine in this study (rat choroid plexus primary cell cultures) compared favorably with the $K_{\mathrm{m}}$ of $39.3 \mu \mathrm{m}$ reported previously for carnosine in isolated choroid plexus experiments (Teuscher et al. 2001). The preferential and high-affinity uptake of carnosine further support the belief that PEPT2 serves as an efflux pump to clear peptides from the CSF. PEPT2 is well suited for this task as its $K_{\mathrm{m}}$ values are generally in the $\mu \mathrm{M}$ range for most di- and tripeptides. Working in concert with apically expressed peptidases in the choroid plexus (Smith et al. 2004), PEPT2 can effectively clear low concentrations of neuropeptides and/or their metabolites. A lack of inhibition by the constituent amino acids of carnosine (i.e. $\beta$-alanine and L-histidine), coupled with the stability of intact radiolabel, indicate that carnosine metabolism is not a confounding factor in these experiments. In addition, the peptide/histidine transporters, PHT1 and PHT2, do not appear to mediate carnosine uptake as demonstrated by the lack of inhibition by L-histidine at concentrations 50 times its $K_{\mathrm{m}}$ value (Yamashita et al. 1997) and because of results in the PEPT2 transgenic mice.

The studies in transgenic mice clearly demonstrate that PEPT2 accounts for over $90 \%$ of carnosine's uptake in choroid plexus whole tissue. The lack of difference in null animals as a function of sodium (normal- $\mathrm{Na}^{+}$vs. low- $\mathrm{Na}^{+}$ aCSF buffer) suggests that residual sodium-dependent transport mechanisms are not present. Yet, under low sodium conditions, the uptake of carnosine was reduced by $39 \%$ in wild-type mice. In previous studies (Novotny et al. 2000; Teuscher et al. 2001), this finding would have been mistakenly interpreted as PEPT2 being responsible for $61 \%$ of carnosine's uptake with another $39 \%$ being handled by $\mathrm{Na}^{+}$-dependent processes. As a result, one must use caution when interpreting data from different buffer conditions. Although PEPT2-mediated transport is proton-coupled, as opposed to being $\mathrm{Na}^{+}$-coupled, it is a tertiary active process that depends on prior sodium and hydrogen ion gradients being established. To further probe this relationship, we studied the effect of a $\mathrm{Na}^{+} / \mathrm{H}^{+}$exchange inhibitor, dimethyl amiloride (1 mM), on the apical uptake of $\left[{ }^{3} \mathrm{H}\right]$ carnosine $(1 \mu \mathrm{M})$ in rat choroid plexus primary cell cultures. Using normal-Na ${ }^{+}$aCSF buffer conditions, carnosine uptake was inhibited by $88 \% \quad(p<0.01$ as compared with control values), demonstrating the profound influence of $\mathrm{Na}^{+} / \mathrm{H}^{+}$exchange on the PEPT2-mediated transport of a dipeptide.

Although speculative, the minor inhibition observed by some organic anions (i.e. SITS and GABA, but not TCA and $\mathrm{PAH}$ ) and cations (i.e. NMN and TEA, but not choline) probably reflects alterations in membrane potential and/or microclimate $\mathrm{pH}$, thereby resulting in reduced uptake of carnosine in choroid plexus. It is highly unlikely that other transporters are involved because, as shown in this study, PEPT2 appears to account for essentially all of carnosine's transport into choroid plexus. As shown with GlySar (Shen et al. 2003) and cefadroxil (Ocheltree et al. 2004) in 
transgenic mice, only $5 \%$ of choroid plexus uptake occurs, in general, by non-specific processes.

In conclusion, these studies are unique in first demonstrating the preferential apical uptake of an endogenous neuropeptide at the BCSFB, and the importance of PEPT2 in this process. These findings establish that PEPT2 is responsible for over $90 \%$ of carnosine's choroid plexus uptake, and suggest a critical role for PEPT2 in neuropeptide homeostasis in the central nervous system. Although PEPT2 transports a wide range of di- and tripeptides, peptide disposition may vary once in the cell. Thus, some peptides may be accumulated in the choroid plexus, as observed in this study for carnosine. Others may be effluxed into blood, as found for GlySar (Shu et al. 2002). Yet others may be metabolized intracellularly by the choroid plexus and then recycled. In order to more completely understand the role of PEPT2 in the brain, our laboratory is currently investigating the in vivo pharmacokinetics and tissue distribution of peptides/mimetics in wild-type and PEPT2 knockout mice.

\section{Acknowledgements}

This study was supported in part by Grants R01 GM035498 (to DES) and R01 NS034709 and P01 HL018575 (to RFK) from the National Institutes of Health. NST was supported by an American Foundation for Pharmaceutical Education Pre-Doctoral Fellowship and the Pharmacological Sciences Training Program of the National Institutes of Health (Grant T32 GM007767).

\section{References}

Berger U. V. and Hediger M. A. (1999) Distribution of peptide transporter PEPT2 mRNA in the rat nervous system. Anat. Embryol. (Berl.) 199, 439-449.

Boldyrev A. A., Stvolinsky S. L., Tyulina O. V., Koshelev V. B., Hori N. and Carpenter D. O. (1997) Biochemical and physiological evidence that carnosine is an endogenous neuroprotector against free radicals. Cell Mol. Neurobiol. 17, 259-271.

Bradford M. M. (1976) A rapid and sensitive method for the quantitation of microgram quantities of protein utilizing the principle of proteindye binding. Anal. Biochem. 72, 248-254.

Chung-Hwang E., Khurana H. and Fisher H. (1976) The effect of dietary histidine level on the carnosine concentration of rat olfactory bulbs. J. Neurochem. 26, 1087-1091.

Daniel H. and Herget M. (1997) Cellular and molecular mechanisms of renal peptide transport. Am. J. Physiol. 273, F1-F8.

Ferriero D. and Margolis F. L. (1975) Denervation in the primary olfactory pathway of mice. II. Effects on carnosine and other amine compounds. Brain Res. 94, 75-86.

Hipkiss A. R. (1998) Carnosine, a protective, anti-ageing peptide? Int. J. Biochem. Cell Biol. 30, 863-868.

Hipkiss A. R., Preston J. E., Himsworth D. T., Worthington V. C., Keown M., Michaelis J., Lawrence J., Mateen A., Allende L., Eagles P. A. et al. (1998) Pluripotent protective effects of carnosine, a naturally occurring dipeptide. Ann. NY Acad. Sci. 854, $37-53$.

Horning M. S., Blakemore L. J. and Trombley P. Q. (2000) Endogenous mechanisms of neuroprotection: role of zinc, copper, and carnosine. Brain Res. 852, 56-61.
Kish S. J., Perry T. L. and Hansen S. (1979) Regional distribution of homocarnosine, homocarnosine-carnosine synthetase and homocarnosinase in human brain. J. Neurochem. 32, 1629-1636.

Leibach F. H. and Ganapathy V. (1996) Peptide transporters in the intestine and the kidney. Annu. Rev. Nutr. 16, 99-119.

Liu W., Liang R., Ramamoorthy S., Fei Y. J., Ganapathy M. E., Hediger M. A., Ganapathy V. and Leibach F. H. (1995) Molecular cloning of PEPT 2, a new member of the $\mathrm{H}^{+}$/peptide cotransporter family, from human kidney. Biochim. Biophys. Acta 1235, 461-466.

Marchis S. D., Modena C., Peretto P., Migheli A., Margolis F. L. and Fasolo A. (2000) Carnosine-related dipeptides in neurons and glia. Biochemistry (Mosc.) 65, 824-833.

Margolis F. L. (1974) Carnosine in the primary olfactory pathway. Science 184, 909-911.

Novotny A., Xiang J., Stummer W., Teuscher N. S., Smith D. E. and Keep R. F. (2000) Mechanisms of 5-aminolevulinic acid uptake at the choroid plexus. J. Neurochem. 75, 321-328.

O’Dowd J. J., Cairns M. T., Trainor M., Robins D. J. and Miller D. J. (1990) Analysis of carnosine, homocarnosine, and other histidyl derivatives in rat brain. J. Neurochem. 55, 446-452.

Ocheltree S. M., Shen H., Hu Y., Xiang J., Keep R. F. and Smith D. E. (2004) Mechanisms of cefadroxil uptake in the choroid plexus: studies in wild type and PEPT2 knockout mice. J. Pharmacol. Exp. Ther. (in press).

Preston J. E., Hipkiss A. R., Himsworth D. T., Romero I. A. and Abbott J. N. (1998) Toxic effects of $\beta$-amyloid (25-35) on immortalised rat brain endothelial cell: protection by carnosine, homocarnosine and $\beta$-alanine. Neurosci. Lett. 242, 105-108.

Sakata K., Yamashita T., Maeda M., Moriyama Y., Shimada S. and Tohyama M. (2001) Cloning of a lymphatic peptide/histidine transporter. J. Biochem. 356, 53-60.

Shen H., Smith D. E., Keep R. F., Xiang J. and Brosius F. C. III (2003) Targeted disruption of the PEPT2 gene markedly reduces dipeptide uptake in choroid plexus. J. Biol. Chem. 278, 4786-4791.

Shu C., Shen H., Teuscher N. S., Lorenzi P. J., Keep R. F. and Smith D. E. (2002) Role of PEPT2 in peptide/mimetic trafficking at the bloodcerebrospinal fluid barrier: studies in rat choroid plexus epithelial cells in primary culture. J. Pharmacol. Exp. Ther. 301, 820-829.

Smith D. E., Johanson C. E. and Keep R. F. (2004) Peptide and peptide analog transport systems at the blood-CSF barrier. Adv. Drug Deliv. Rev. in press.

Strazielle N. and Ghersi-Egea J. F. (1999) Demonstration of a coupled metabolism-efflux process at the choroid plexus as a mechanism of protection toward xenobiotics. J. Neurosci. 19, 6275-6289.

Stvolinsky S. L., Kukley M. L., Dobrota D., Matejovicova M., Tkac I. and Boldyrev A. A. (1999) Carnosine: an endogenous neuroprotector in the ischemic brain. Cell Mol. Neurobiol. 19, 45-56.

Teuscher N. S., Novotny A., Keep R. F. and Smith D. E. (2000) Functional evidence for presence of PEPT2 in rat choroid plexus: studies with glycylsarcosine. J. Pharmacol. Exp. Ther. 294, 494-499.

Teuscher N. S., Keep R. F. and Smith D. E. (2001) PEPT2-mediated uptake of neuropeptides in rat choroid plexus. Pharm. Res. 18, 807-813.

Wang H., Fei Y.-J., Ganapathy V. and Leibach F. H. (1998) Electrophysiological characteristics of the proton-coupled peptide transporter PEPT2 cloned from rat brain. Am. J. Physiol. 275, C967C975.

Ward R. J. and Preedy V. R. (1992) Imidazole dipeptides in experimental alcohol-induced myopathy. Alcohol 27, 633-639.

Yamashita T., Shimada S., Guo W., Sato K., Kohmura E., Hayakawa T., Takagi T. and Tohyama M. (1997) Cloning and functional expression of a brain peptide/histidine transporter. J. Biol. Chem. 272, 10205-10211. 